\title{
Miskonsepsi Siswa dalam Memahami Konsep Nilai Tempat Bilangan Dua Angka
}

\author{
Christi Matitaputty \\ Universitas Pattimura \\ e-mail: christi_matitaputty@yahoo.co.id
}

\begin{abstract}
ABSTRAK
Konsep-konsep matematika yang diberikan pada tingkat Sekolah Dasar merupakan konsep dasar yang berguna untuk pemahaman matematika di tingkat selanjutnya. Adanya miskonsepsi membuat pembelajaran menjadi tidak bermakna dan hubungan antar konsep menjadi terputus. Banyak hal yang menyebabkan terjadinya miskonsepsi dalam memahami nilai tempat bilangan dua angka, diantaranya dari siswa itu sendiri yang belum memahami makna nilai tempat bilangan dua angka. Penelitian ini mengungkapkan bahwa beberapa siswa belum dapat mengembangkan ide bahwa 'ratusan' merupakan suatu kumpulan baru yang berisikan sepuluh puluhan dan 'puluhan' merupakan suatu kumpulan baru yang berisikan sepuluh satuan. Penelitian ini dilakukan pada siswa Kelas 2 SD Negeri 179 Palembang. Tujuan dari penelitian ini adalah mendeskripsikan beberapa kesalahan konsep yang dibuat oleh siswa dalam memahami nilai tempat bilangan dua angka. Hasil penelitian menunjukan beberapa miskonsepsi siswa diantaranya adalah (1) Siswa belum mamahami prosedur dalam menghitung dan memisahkan bilangan satuan dan puluhan. (2) siswa mempunyai alternatif konsep lain tentang bilangan dua digit dan membaca bilangan tersebut sebagai bilangan yang terlepas dari suatu nilai tempat, (3) siswa memiliki alternatif konsep lain dalam memahami penjumlahan angka puluhan dan satuan.
\end{abstract}

Kata kunci: Miskonsepsi, nilai tempat bilangan dua angka

\begin{abstract}
Mathematical concepts are given at the elementary school level is a basic concept that is useful for understanding mathematics at the next level. Their misconceptions make learning becomes no meaningful and the relationships between concepts become disconnected. Many factors led to misconceptions in understanding the value of a two digit number, such as from the students themselves who do not understand the meaning of the place value of two digit numbers. This study revealed that some students have not been able to develop the idea that 'hundreds' is a new collection containing ten tens and 'tens' is a new collection containing ten units. Research was conducted on Second Grade students at SD Negeri 179 Palembang. The purpose of this study are describe some of the misconceptions created by the students in understanding the value of a two-digit number. The results showed some misconceptions students such as; (1) Students are not understanding the procedures in counting and separating the units and tens. (2) the students have another alternative conceptions of two-digit numbers and they read these numbers as numbers that apart from a place value, (3) the students have another alternative concepts in understanding the sum of the tens and sum units.
\end{abstract}

Keywords: Misconception, place value of two-digit number

\section{PENDAHULUAN}

Dalam pembelajaran matematika dikenal istilah objek matematika. Salah satu objek langsung matematika yang berperan penting dalam pembelajaran adalah konsep. Konsep adalah ide abstrak atau gagasan yang dibentuk dengan memandang sifat-sifat yang sama dari sekumpulan eksemplar yang cocok atau ide abstrak yang dapat digunakan untuk mengkasifikasikan sekumpulan objek. Selain itu, konsep dapat diartikan sebagai ide atau gagasan yang abstrak yang terbentuk berdasarkan pengalaman siswa dengan tujuan mempermudah siswa untuk berkomunikasi dan memungkinkan siswa untuk berpikir sesuai dengan peristiwa dan fakta serta mengidentifikasi setiap konsep. Terkait dengan hal ini, siswa sebenarnya telah 
memiliki konsep awal yang berasal dari pengalaman hidup mereka sebelum mereka mengikuti pembelajaran secara formal di sekolah. Konsep awal ini disebut sebagai konsepsi. Jika siswa memiliki konsep awal yang tidak sesuai dengan konsep ilmiah maka hal ini disebut dengan miskonsepsi. Menurut Purtadi dan Sari (dalam Disnawati \& Putri, 2011) miskonsepsi didefinisikan sebagai pengetahuan konseptual dan proporsional siswa yang tidak konsisten atau berbeda dengan kesepakatan ilmuan yang telah diterima secara umum dan tidak dapat menjelaskan secara tepat fenomena ilmiah yang diamati. Dengan demikian, miskonsepsi tidak hanya dipandang sebagai sebuah pengertian yang tidak akurat tentang konsep namun dapat artikan sebagai penggunaan konsep yang salah bahkan pemaknaan konsep yang berbeda dan hubungan hirarkis konsep yang keliru.

Konsep-konsep dalam matematika tersusun secara hirarkis, terstuktur, logis dan sistematis dimulai dari konsep yang sederhana sampai kepada konsep yang kompleks. Pembelajaran matematika ibarat mata rantai yang saling berkesinambungan dan membuat rantai itu menjadi utuh. Konsep dalam matematika saling berkaitan bahkan konsep yang sederhana memiliki peranan sebagai konsep prasyarat untuk menuju pemahaman konsep yang lebih kompleks. Terjadinya miskonsepsi dalam pembelajaran matematika di tingkat sekolah dasar merupakan suatu hal yang fatal karena konsep awal yang dimiliki tidak akan berkembang dengan baik untuk memahami konsep selanjutnya. Jika suatu materi pelajaran matematika tidak terkoneksikan dengan baik maka dapat mengakibatkan siswa sulit mengembangkan kemapuan berpikir logis dan matematis.

Pembelajaran nilai tempat merupakan suatu pembelajaran yang mendapat perhatian penting dalam kurikulum pendidikan di tingkat Sekolah Dasar. Hal ini dapat diperhatikan melalui pemahaman nilai tempat pada bilangan cacah yang berkembang dari kelas 1 hingga kelas 4 kemudian berkembang menuju pemahaman nilai tempat bilangan desimal di kelas 5 dan 6 (Matitaputty, dkk., 2013). Di kelas 1 Sekolah Dasar siswa diharapakan mampu memahami nilai tempat bilangan dua angka (puluhan dan satuan), selanjutnya di kelas 2 siswa diharapkan memahami nilai tempat bilangan tiga angka (ratusan, puluhan dan satuan). Jika siswa tidak menguasai konsep nilai tempat dua angka dengan baik maka mereka akan menghadapi kesulitan dalam memahami konsep nilai tempat bilangan tiga angka. Selanjutnya, siswa juga akan kesulitan dalam memberi nama suatu bilangan demikian sebaliknya siswa akan mengalami kesulitan dalam menuliskan lambang bilangan jika diketahui lambang suatu bilangan (Handayani, 2011). Nilai tempat tidak saja berguna dalam membaca dan menuliskan bilangan terlebih lagi pemahaman yang benar terhadap nilai tempat suatu bilangan akan membantu siswa dalam memahami operasi bilangan seperti penjumlahan, pengurangan, perkalian dan pembagian.

Nilai tempat merupakan konsep matematika yang fundamental bagi siswa dalam belajar matematika. Jika terjadi miskonsepsi dalam pembelajaran materi nilai tempat maka siswa akan memiliki kelemahan dalam aritmatika.

Miskonsepsi sering ditemui dalam pembalajaran nilai tempat bilangan dua angka dan tiga angka. Hal ini dapat terjadi dikarenakan guru memiliki pengetahuan yang terbatas tentang konsep nilai tempat lewat buku pembelajaran yang tersedia disekolah ataupun buku pelajaran lainnya yang isinya hanya memuat definisi dan contoh. Hal ini membuat pemahaman guru menajdi terbatas karena guru belum dapat terfasilitasi untuk mengembangkan konsep materi tersebut. Dengan demikian, apa yang disampaikan guru menjadi kurang dipahami oleh siswa dan 
siswa dapat saja membuat kekeliruan dan salah konsep.

Kesalahan konsep tidak saja berujung pada kekeliruan siswa namun hal ini dapat menjadi kesulitan belajar pada materi selanjutnya bagi siswa. Beberapa penelitian sebelumnya telah mencatat kesulitankesulitan belajar siswa dalam memahami nilai tempat diantaranya yaitu (1) kesulitan belajar dialami siswa dalam penjumlahan dengan teknik menyimpan oleh karena siswa belum memahami simbol dalam matematika, pemahaman nilai tempat, penggunaan proses yang keliru, perhitungan dan belum lancar dalam bahasa dan membaca (Lestari, 2012). Kekeliruan lainnya yang dibuat oleh siswa adalah kesalahan dalam menulis nama dan lambang bilangan, mendefinisikan nilai tempat sebuah bilangan terutama angka nol yang teletak diantara dua digit lainnya (Harmini \& Roebyanto,2003). Kesalahan dan kesulitan siswa diatas menunjukan bahwa kurangnya pemahaman nilai tempat bagi siswa sekolah dasar. Sebagai fasilitator pembelajaran, guru hendaknya memiliki kemampuan untuk mengenali dan menggali pengetahuan awal siswa, terutama pengetahuan awal yang salah agar tidak terjadi miskonsepsi yang berkepanjangan. Selain itu, guru juga hendaknya memiliki kemampuan untuk mengatasi miskonsepsi yang terjadi pada siswa. Dengan demikian tulisan ini bertujuan untuk mengidentifikasi miskonsepsi yang terjadi pada siswa kelas 2 Sekolah Dasar dalam pembelajaran konsep nilai tempat. Penelitian ini secara keseluruhan telah dilakukan untuk kelas 2 SD untuk menjawab kompetensi dasar memahami nilai tempat bilangan ratusan. Akan tetapi, sebelum siswa belajar materi nilai tempat bilangan tiga angka guru perlu memberikan pemahaman nilai tempat bilangan dua angka. Sehingga, tulisan ini berfokus pada miskonsepsi siswa dalam memahami nilai tempat bilangan dua angka. Penelitian ini bermanfaat bagi para guru maupun calon guru untuk menjadi bahan masukan untuk memahami miskonsepsi siswa, mengenal penyebab dan kiat-kiat untk mengatasi miskonsepsi baik pada siswa khusunya pada materi nilai tempat bilangan dua angka.

\section{METODE}

Metode penelitian yang digunakan adalah metode deskriptif dengan menggunakan pendekatan kuantitatif. Penelitian deskriptif adalah penelitian yang berusaha untuk menuturkan pemecahan masalah yang ada sekarang berdasarkan datadata, mencakup menyajikan data, menganalisis data, dan menginterpretasi data (Cholid Narbuko, 2005:44), dengan demikian penelitian ini akan mengungkapkan dan mendeskripsikan miskonsepsi siswa terhadap materi nilai tempat bilangan dua angka. Subjek penelitian ini adalah 30 siswa kelas 2 SD Negeri 179 Palembang dan satu orang guru dilibatkan sebagai guru model dalam penelitian ini. Peneliti hadir dalam penelitian ini dan berperan sebagai observer yang mengamati jalannya penelitian. Penelitian ini berlansung dalam waktu kurang lebih 1 bulan dengan 6 kali pertemuan pada tahap percobaan kelas penelitian (teaching experiment). Sumber data yang diperoleh berasal dari video rekaman yang diletakan didepan kelas untuk merekam kejadian secara klasikal dan kamera saku yang digunakan untuk mengambil setiap peristiwa penting selama proses pembelajaran didalam kelompok, selain itu untuk mengecek keabsahan data maka peneliti juga melakukan wawancara mendalam dengan sisiwa terhadap hasil kerja siswa dalam bentuk LKS. Data mengenai jalannya kegiatan belajar mengajar, hasil pekerjaan siswa (LKS) dan wawancara dengan siswa dianalisis secara deskriptif untuk menjelaskan penguasaan siswa terhadap konsep nilai tempat bilangan dua angka. Selain itu peneliti juga berdiskusi dengan guru untuk menghindari sudut pandang peneliti sendiri dan untuk mengurangi subjektivitas peneliti dalam 
menginterpretasi data hasil penelitian yang diperoleh di lapangan.

\section{HASIL DAN PEMBAHASAN}

Terdapat 3 bentuk aktivitas yang akan dibahas terkait dengan miskonsepsi yang ditemukan selama proses pembelajaran berlangsung. Aktifitas pertama adalah siswa diminta untuk melakukan hand-on counting / menghitung sejumlah manipulative udang. Proses menghitung manipulative udang ini akan menggiring siswa untuk menemukan strategi yang terbaik dalam menghitung suatu kuantitas yang besar yaiut dengan pengelompokan sepuluh. Pengelompokan sepuluh dipandang sebagai suatu proses unitizing dimana muncul identitas baru dari kelompokan sepuluh dengan suatu nama baru yang disebut puluhan dan selanjutnya pengelompokan sepuluh puluhan diberi nama ratusan. Selain untuk melihat strategi pengelompokan, kegiatan ini juga bertujuan untuk melihat kemampuan menghitung bilangan sambil menyebutkan nama bilangan tersebut. Adapun setiap kelompok diberikan jumlah manipulative udang yang berbedabeda berkisar 40 sampai dengan 50 manipulatif disetiap kelompok. Setiap kelompok bekerja secara berpasangan. Adapun pertanyaan dalam LKS meliputi ; Berapa jumlah manipulative udang? Dan bagaimana cara kamu menghitungnya?. Setelah siswa diberi kesempatan untuk meghitung dan mengelompokan manipulative udang maka setiap kelompok diminta untuk mempresentasikan hasil pekerjaan mereka di depan kelas, mereka diminta untuk bercerita kembai bagaimana mereka mengelompokan dan menghitung manipulative tersebut.

Miskonsepsi yang terjadi pada aktivitas pertama ini adalah terdapat siswa (kelompok 2) yang menhitung dan membuat pengelompokan manipulative dalam pengelompokan sepuluh namun ketika siswa diminta untuk menghitung atau membilang suatu kumpulan/objek yang sudah mereka susun dalam 4 ikatan puluhan dan 6 satuan, siswa melakukan perhitungan 10, 20, 30, 40 kemudian 1, 2, 3, 4, 5 dan 6 yang seharusnya 10, 20, 30, 40, 41, 42, 43, 44, 45 dan 46. (Perhatikan gambar 1)

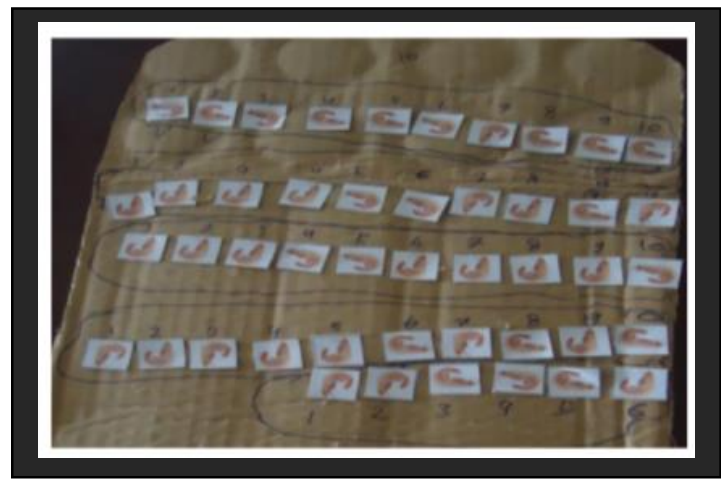

Gambar 1. Hasil Pengelompokan manipulative Kelompok 2 (V dan N)

Berikut wawancara peneliti (P) dan $\mathrm{V}$ \& N (siswa).

P : V coba kamu hitung kembali berapa jumlah udang yang sudah kamu kelompokan?

$\mathrm{V}:$ satu, dua, tiga empat,.... Sepuluh(sambil menunjukan manipulative udang satu-satu)

$\mathrm{N}$ : bukan begitu, ini ada sepuluh, terud dua puluh, tiga puluh, empat puluh dan terakhir satu, dua, tiga, empat, lima dan enam bu

$\mathrm{P}$ : $\quad$ benar $\mathrm{V}$ apa yang dihitung $\mathrm{N}$ ?

V: Diam

$\mathrm{P}$ : berapa jumlah keseluruhan udang yang sudah kamu hitung

$\mathrm{N}$ : Empat enam bu.

Analisis video rekaman dan wawacara peneliti menunjukan bahwa siswa dalam kelompok ini belum memahami nilai tempat atau posisi dari angka yang mempresentasikan bilangan tersebut. Selain itu, mereka juga belum dapat memahami prosedur dalam menghitung dan memisahkan bilangan puluhan dan satuan. Siswa dalam kelompok ini menyebutkan nama bilangan itu secara terpisah berdasarkan cara mereka membuat kelompok dan menghitung satu- 
satu. Meskipun siswa ini bisa membuat pengelompokan sepuluh namun menyatukan sepuluh dalam sebuah kumpulan yang saling menyatu dengan sepuluh lainnya membentuk penjumlahan masih terasa sulit bagi siswa. Mereka hanya mampu membaca bilangan secara terpisah dan belum dapat memahami posisi setiap angka punya makna berbeda dan nilai yang berbeda.

Selanjutnya pada aktivitas 2 siswa diminta untuk melakukan kegiatan bertukar dengan manipulative. Aturannya siswa harus menukarkan sepuluh udang untuk satu kepiting. Jika sisa udang kurang dari sepuluh maka disebut sebagai udang lebih. Setelah mereka berhasil melakukan proses pertukaran maka jumlah udang keseluruhan, jumlah kepiting yang berhasil ditukar dan udang lebih yang tidak dapat di tukar di data kedalam tabel. Saat kelompok mendata hasil tersebut, terlihat kesalahan yang dibuat salah seorang siswa (NT) (gambar 2) dan dikomentari oleh teman-teman lainnya.

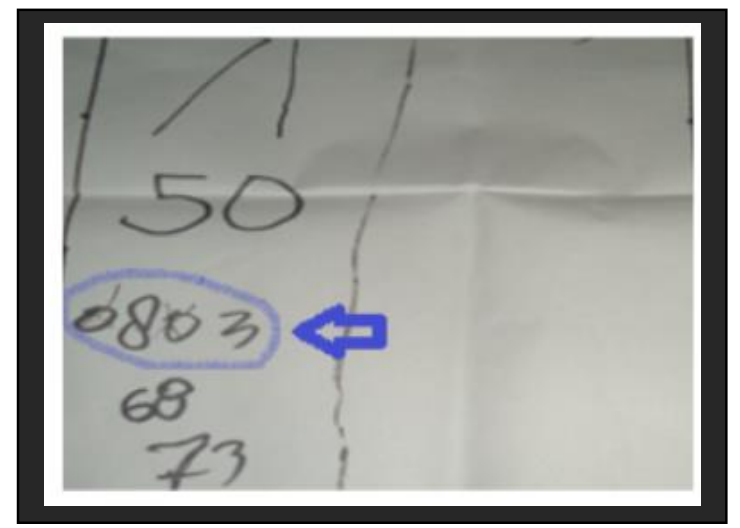

Gambar 2. Kesalahan NT dalam menuliskan bilangan 83

Berikut percakapan yang dilakukan peneliti secara kalsikal saat kesalahan ini terjadi.

P : Mengapa nata menuliskan 0803? apa artinya ini?

NT : Salah bu...

$\mathrm{P} \quad$ : jadi, apa maksudnya $\mathrm{N}$ ?

NT : delapan puluh tiga, itu bu... sambil menunjuk ke arah bilangan yang ditulis

E cak nyo itu (maksudnya itu) tidak ada nol

$\mathrm{K}$ : harusnya kosong delapan tiga

$\mathrm{P}$ : mengapa ada kosong didepan? Apa selama ini ada bilangan yang ditulis dengan kosong didepan? Mengapa yang lainnya tidak menulis dengan kosong didepan hanya $\mathrm{N}$ ?

$\mathrm{P}$ : Kira-kira siapa yang bisa membaca angka ini? selain kosong? Ayo dibaca apa angka ini? (sambil menunjukan angka nol)

$\mathrm{B}$ : Dibaca nol Bu

$\mathrm{P}$ : Iya benar, angka ini dibaca nol bukan kosong

NT : hmmmm (berpikir)

$\mathrm{P}$ : tadi kan menurut Nata jawabannya salah, apa NT bisa mengganti jawabannya? Yang benarnya bagaimana ya NT?

NT : (maju kedepan dan mencoret salah satu angka nol diantara angka 8 dan 3)

$\mathrm{P} \quad$ : mengapa kamu memberi silang angka nol itu NT?

NT : kan salah bu

$\mathrm{P}$ : mengapa tadi NT menulis nol didepan angka delapan? Apakah teman-teman lain juga menuliskan nol didepan sebuah lambang bilangan?

NT : tidak (sambil mencoret/menyilang angka nol didepan).

P : sekarang, kalau NT menulis angka, apakah selalu ada nol didepan sebuah lambang bilangan?

NT : tidak bu

Kesalahan siswa dalam membaca bilangan dan menuliskan bilangan 83 disebabkan oleh karena siswa siswa mempunyai alternatif konsep tentang bilangan dua digit dan membacanya sebagai bilangan yang terlepas dari suatu nilai tempat. Dengan demikian, ketika siswa menuliskan delapan puluh tiga, siswa tersebut menuliskan sebagai 803 dan siswa mengalami miskonsepsi nilai tempat bilangan dua angka. Dalam penelitian ini miskonsepsi ini sudah diprediksi diawal 
sehingga guru dapat dengan segera memimbing siswa untuk menyadari dan memperbaikin kesalahan yang dibuatnya.

Selanjutnya miskonsepsi siwa juga terjadi pada aktifitas memahami nilai tempat bilangan dua angka.

\section{4 puluhan +3 satuan $=7$. . .}

Gambar 1. Kesalahan Siswa U

\section{$25=20$ puluhan.+ .5 satuan}

Gambar 2. Kesalahan Siswa LL

Berdasarkan gambar 1 diatas maka dapat diperhatikan bahwa siswa $U$ melakukan kesalahan dengan menuliskan 4 puluhan +3 satuan $=7$ (gambar 1$)$. Hal ini terjadi oleh karena siswa tidak memahami 4 puluhan. Kata puluhan tidak dapat dipahami sebagai suatu kumpulan baru yang berisikan sepuluh satuan. Sehingga siswa cenderung memiliki alternatif konsep lain dalam memahami penjumlahan 4 puluhan +3 satuan sebagai penjumlahan dari $4+3=7$. Siswa lebih focus pada angka bukan pada arti dari angka puluhan. Permasalahan selanjutnya dijumpai pada siswa LL (gambar 2). Adanya misonsepsi terlihat dari hasil pekerjaan LL yang menuliskan $25=20$ puluhan +5 satuan. Hal ini menandakan bahwa siswa tidak memahami arti kata puluhan sebagai suatu kumpulan baru yang terdiri dari sepuluh satuan. Kemungkinan siswa ini cenderung berpikir dan berfokus pada bilangan 25 sebagai bentuk penguraian atau penjumlahan $20+5$ dan tidak memperhatikan kata puluhan yang mengharuskan siswa untuk mengisi sebuah angka puluhan.

\section{PENUTUP}

Kesimpulan

Masih terdapat beberapa siswa Sekolah Dasar yang mengalami miskonsepsi pada materi nilai tempat bilangan cacah. Berntuk kesalahan yang dilakukan antara lain sebagai berikut:

1. Miskonsepsi dalam memahami nilai tempat atau posisi dari angka yang merepresentasikan sebuah bilangan sehingga terjadi kesalaha dalam memahami prosedur dan menghitung serta memisahkan bilangan puluhan dan satuan.

2. siswa siswa mempunyai alternatif konsep tentang bilangan dua digit dan membacanya sebagai bilangan yang terlepas dari suatu nilai tempat.

3. Adanya alternatif konsep lain dalam memahami penjumlahan angka puluhan dan angka satuan.

4. Siswa belum dapat memaknai kata puluhan sebagai suatu kumpulan baru yang terdiri dari sepuluh satuan.

\section{Saran}

Adapun saran yang dapat disampaikan lewat penelitian ini adalah sebagai berikut:

1. Menjadikan tulisan ini sebagai bahan masukan bagi guru dalam memahami miskonsepsi siswa, sehingga guru dapat mengetahui penyebab dan kiatkiat untuk mengatasi miskonsepsi pada materi nilai tempat bilangan dua angka

2. Mengadakan penelitian lebih lanjut tentang pemahaman nilai tempat pada materi penjumlahan dan pengurangan bilangan dua angka dan tiga angka.

\section{UCAPAN TERIMA KASIH}

Terima kasih penulis sampaikan kepada seluruh siswa Kelas 2 SD Negeri 179 
Palembang yang sudah berpartisipasi sebagai subjek penelitian baik untuk ujicoba kelas kecil maupun ujicoba kelas penelitian juga guru kelas Ibu Siti Aisyah, S.Pd yang sudah membantu penulis dan berperan sebagai guru model dalam penelitian ini.

\section{DAFTAR PUSTAKA}

Cholid, N dan Abu A. (2005). Metode Penelitian. Bumi Aksara. Jakarta

Disnawati, H, dan Putri, R. I. I. (2012). Miskonsepsi Guru Sekolah Dasar Dalam Aktivitas Pembelajaran Materi Segi Empat Pada Workshop PMRI di Palembang. Prosiding Seminar Nasional Pendidikan, ALPTKSI-UPGRI, Palembang, 15 Desember, 401-410

Handayani,Y. (2011). Upaya Meningkatkan Hasil Belajar Matematika Tentang Nilai Tempat Di Kelas IV Sekolah Dasar Negeri Cicadas 01 Kecamatan Gunung Putri Kabupaten Bogor Melalui Pembelajaran Dengan Menggunakan Alat Peraga Blok Model Dienes Dan Abakus (Penelitian Tindakan Kelas). Reprositori Universitas Pendidikan Indonesia

Harmini,S., \& Roebyanto,G.(2003). Mengatasi Kesalahan Siswa Dalam memahami Konsep Nilai Tempat Suatu Bilangan Di Kelas 5 SD Negeri Madyopuro 3 Kedungkandang Malang. Jurnal Forum Penelitian Kependidikan, Vol 15, No 1

Lestari,D. P. (2012). Deskripsi Kesulitan Belajar Pada Operasi Penjumlahan Dengan Teknik Menyimpan Siswa Kelas I SD N 3 Panjer Kecamatan Kebumen Tahun Ajaran 2011/2012 . Jurnal FKIP Pendidikan Universitas Sebelas Maret
Matitaputty, C, Putri, R. I.I dan Hartono, Y.(2013). Memahami Nilai Tempat Dengan Kegiatan Bertukar Biota Laut Untuk Kelas II Sekolah Dasar. Jurnal Edukasi matematika (EduMath) 4 (7). Juni 2013, 439450. http://eprints.unsri.ac.id/3777/.

\section{RIWAYAT HIDUP PENULIS}

Christi Matitaputty, S.Pd., M.Pd. Lahir

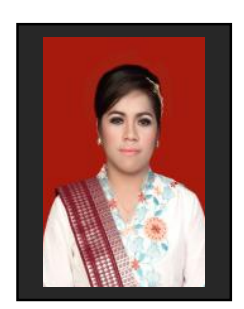

di Ambon, pada tanggal

$01 \quad$ November 1987.

Dosen tetap di Universitas Pattimura, Studi S1 Pendidikan Matematika Universitas Pattimura, Ambon, lulus pada tahun 2010. Dan S2 Pendidikan Matematika di Universitas Sriwijaya, Palembang, lulus tahun 2013. 